a short part of its transit, and passing behind the roofs of some hou es was immediately lost to sight.

Bregner, Bournemouth, March 20

HENRY CECIL

P.S.-If a line be drawn north and south, the meteor became visible at a point due east, which direction I was facing.

\section{THE BRITISH CIRCUMPOLAR EXPEDITION 1}

THE journey to Fort Rae, though long, was full of interest and variety. Our party, consisting of myself, two sergeants, and an artificer, of the Royal Artillery, left Winnipeg on June 9 by steamer for Fort Carlton, on the Saskatchewan, viâ Lake Winnipeg. We were detained a day in that lake by ice, but reached the mouth of the Saskatchewan on the I3th, where we were delayed four days trans-shipping cargo to the river steamer, which lay three miles off at the upper end of the rapids; a tedious voyage of eight days took us to Carlton, a stockaded port on the south bank of the river. For the first three days the country seemed one immense swamp, with numerous shallow lakes; then the ban'rs gradually grow higher, till at "the Forks" (the confluence of the north and south branches of the Saskatchewan) they are about 150 feet above the river. Here the soil seems very rich and fertile, and about the new settlement of Prince Albert, a day higher up, the country is quite English in appearanceundulating, covered with rich grass, with woods here and there-a far more attractive-looking country than the flat, treeless prairie near Winnipeg.

From Carlton, after a day or two spent in hiring transport carts, we started on the 3oth with a train of ten carts, containing our provisions and baggage. The country was very pretty, well wooded and watered, with duck, snipe, and prairie chicken in abundance; it was at times difficult to believe one was not in an English park. But the most vivid imagination cannot picture the swarms of mosquitoes that at times attacked us: they came against our faces like flakes in a heavy snowstorm, and though we found our veils and gloves a good protection whilst travelling, yet, when mealtimes came, veils had to be laid aside, and the wretched insects seized the opportunity of taking their meal too.

On the third day of our journey, on reaching the crest of some rising ground, an extended view opened before us, ridge behind ridge, a sombre sea of pinewood stretching away in the distance. It was the great sub-Arctic forest which extends northwards to the barren grounds at the Arctic circle and east and west to the Atlantic and the Pacific. On entering the woods the mosquitoes were not quite so bad, but our unfortunate animals became the prey of an enormous horsefly, whicb settled on them in thousands, biting them till they were streaming with blood. Fortunately they only came out during the heat of the day, and we were sometimes obliged to make a balt and light fires so that the animals might stand in the smoke, which they were very willing to do ; indeed they often put a newly-lighted fire out by rolling in it.

'The road through the woods was very bad, and breakdowns were numerous, but at last on July 9 we reached Green Lake, which we left by boat on the I I th for lle à la Crosse. Our conveyance was now one of the Hudson Bay Company's inland boats, with a crew of eight Indians. As we had the stream with us, we were able to drift all night, only landing when we required to cook; so we reached lle d la Crosse early on the i 4 th.

We left it the same evening with a crew of eight Chipewyans, the best crew we ever had. I think they must have pulled sixty miles on one day, the day after we left the fort. On the evening of that day we had an aurora shortly after sunset, which is unusually early in

I Letter from Capt. Dawson, R.A., in command of the Expedition See p. 243. the evening for one. This one appeared to be remarkably close, from its rapid motion and from its being between us and a cirro-cumulus cloud. It was accompanied by a distinct swishing noise like the sound of a sharp squall in a ship's rigging, or the noise a whip makes in passing through the air. I have not heard it $\sin$ e, though there have been plenty of auroras, but from what I have been told by those who have passed their lives in the country, I am of opinion that this sound is occasionally, though rarely, heard, and that it would be heard oftener were it not that the aurora is generally at too great a height.

Two more days brought us to Portage la Loche, a track of some fourteen miles across the watershed dividing the basin of the Arctic Ocean from that of Hudson's Bay. It is fairly level till the last mile, when the edge of the valley of the Clearwater River is reached, some 600 feet above the stream. From this point the view of the valley is very fine, and it strikes one the more from the monotonous nature of the scenery hitherto. The river flows between two ranges of hills, from 800 to I ooo feet in height, and here and there in rapids between limestone cliffs. The first "portage" (where the boats have to be hauled some distance overland) is particularly picturesque, but the whole valley abounds in bits that would delight an artist's eye.

On July 28 we reached the Athabasca River, a fine stream, half a mile or more in width, and the strong current, aided by a fair wind, took us to the lake in it couple of days. There are several springs of naphtha and one of sulphur on the banks.

On crossing Lake Athabasca to Fort Chipewyan, there is a complete change in the character of the country. On the south side the banks are nearly level with the water, all reeds and mud; on the north side is a savage wilderness of Laurentian rock. From a hill at the back of the fort is an extensive view of this strange and desolate country. To the west the lake stretches away to the horizon; on the other side is a mixture of lake, island, and river, and to the north the land, a wilderness of rock in low rounded hills, with a few stunted pines in the valleys, all pretty enough, but so lonely looking.

We were detained a fortnight at Fort Chipewyan till the arrival of the Mackenzie River boats. The heat was at times extreme-as much as $90^{\circ}$ in the house.

The Slave River, or Mackenzie, as it really is, is a magnificent river, especially after its junction with the Peace River, which is at least as big as the Athabasca. The united stream is often a mile in width. About half way to Slave Lake are the rapids, where the scenery is very fine. There are four portages, over three of which the boats had to be hauled, so it was two days' work getting through them. We had a sharp frost on the morning of the roth, the buckets, \&c., that were left with water in them had a quarter of an inch of ice on them in the morning.

On the next evening, while running down the rapid to the last portage, the "Portage des Noyés," after sunset, a bright parhelion made its appearance, some $10^{\circ}$ or $12^{\circ}$ above the horizon. It was of a bright red colour, and threw a brilliant reflection in the water, remaining visible for about twenty minutes, when it changed into a crimsun column, that gradually died away.

On August 22 we reached Fort Resolution-a wretchedlooking place on a flat muddy coast-and the same evening we left for Fort Rae. At sunset the pilot of the boat insisted on stopping for the night at a small rocky island at the mouch of the Slave River. I thought it a pity to stop as we had a fair wind, but the natives of the country have a great dread of lakes, and certainly Great Slave Lake is a stormy place. At midnight a heavy swell suddenly arose, and our boat was stove in and sunk in a very few minutes. It was a pretty wet job to land all the baggage and stores, which of course were all saturated 
with water; but fortunately the instruments all escaped unhurt, and nothing was lost but a pair of boots and a couple of hats, and all our salt and most of our sugar, which the water dissolved.

For the next two days we were employed repairing the boat, it blowing a gale and raining hard the whole time, so that we could dry nothing; and when at last we started, almost constant head-winds and frequent gales made our journey a slow one. Fortunately our course lay among islands, so that we enjoyed a certain degree of shelter from the wind, and harbours of refuge were always at hand in case of necessity. These islands are all of rock and well wooded, but destitute at this season of the year of game, which was unfortunate for us, as our provisions were getting short, and our crew were reduced to a pound of flour per diem, with a little tea and sugar. There were not even fish to be caught, though they are usually abundant, but I suppose the rough weather had driven them into the deep water. At last we shot some seagulls, and we were all glad enough to eat them.

At length, on the 30 th, we reached Fort Rie, which lies in lat. $62^{\circ} 38^{\prime}$ N. an 1 long. I $15^{\circ} 25^{\prime}$ W., half way up a long gulf that run; for about Ios miles in a north-west direction from the mouth of the Yellow Knife River. The fort is situated at the foot of a rocky hill that rises some 200 feet above the lake, which is about four miles wide at this point. The Indians who resort here for trade hunt for the most part in the "barren lands" near the Coppermine River, whence they bring quantities of skins and beef from the musk-ox, which seems to be very abundant. Deer too are very plentiful, and in the winter they migrate in great herds from the barren lands to the country between the arm of the lake on which Fort Rae lies and the Mackenzie. Sometimes these herds pass quite close to the fort, and take two or three days in passing. Their numbers must be very great; a single band has bəen known to kill over 15,000 in an ordinary season.

This year the deer have prssed at som e distance, but the In tians are now bringing in fresh meat daily.

These Indians are of the "Dog-rib" tribe-T'akfwelottine, they call themselves-a quiet, inoffensive race, like all the wood-Indians. They are almost all Roman Catholics, the missionaries of that religion being very nu nerous in the country, and they are certainly very devoted and hard-working. There are also Protestant missionaries, but they do not appear to have made any converts.

The Dor-ribs are a branch of the Chipewyan family which occupies all that portion of the continent between the Rocky Mountains and Hudson's Bay to the north of the parallel of $55^{\circ}$. They are unprepossessing in appearance, and their language is almost unpronounceable by a European. Their alphabet, if they had one, would contain no less than seventy-one letters, that being the number of distinct sounds. I believe the language is allied to the ancient Mexican-at any rate the Navajo is the nearest to it of existing languages-and the combinations of letters that one sees in Mexican names ( $t l$, for instance) are common in this language. The Dog-ribs have the remarkable peculiarity of a national habit of stammering, which is most marked in those who seldom come in to the fort. They treat their women with more kindness than is usual among the American Indians.

Fort Rae is one of the windiest and cloudiest places $I$ have ever seen, but I am told this is an exceptional year. It is certainly a very late autumn ; the lake was not frozen till November 1, and it is only within the last day or two that the cold weather has really set in. Last night the thermometer was at $-34^{\circ}$.

My space is at an end, but by the next mail I hope to give you an account of our winter here.

Fort Rae, December I
ON THE NATURE OF INHIBITION, AND THE ACTION OF DRUGS UPON IT ${ }^{1}$

IV.

$A$ CONDITION very nearly similar to that caused by atropia is produced by morphia. When this substance is given to a frog, its effects are exactly similar to those produced by the successive removal of the different parts of the nervous system from above downwards. Goltz has shown that when the cerebral lobes are removed from the frog it loses the power of voluntary motion and sits still ; when the optic lobes are removed it will spring when stimulated, but loses the power of directing its movements. When the cerebellum is removed it loses the power of springing at all; and when the spinal cord is destroyed reflex action is abolished.

Now these are exactly the effects produced by morphia, the frog poisoned by it first losing voluntary motion, next the power of directing its movements, next the power of springing at all, and lastly reflex action. But after reflex astion is destroyed by morphia and the frog is apparently dead, a very remarkable condition appears, the general flaccidity passes away and is succeeded by a stage of excitement, a slight touch causing violent convulsions just as if the animal had been poisoned by strychnia. ${ }^{2}$

The action of morphia here appears to be clearly that of destroying the function of the nerve centres from above downwards, causing paralysis first of the cerebral lobes, next of the optic lobes, next of the cerebellum, and next of the cord. But it seems probable that the paralysis of the cord first observed is only apparent and not real, and in order to explain it on the ordinary hypothesis we must assume that during it the inhibitory centres in the cord are intensely excite 1 so as to prevent any motor action, that afterwards they become completely paralysed, and thus we get convulsions ozcurring from slight stimuli.

On the hypothesis of interference, the phenomena produced both by atropia and by morphia can be more simply explained. These drugs, acting on the nervous structures, gradually lessen the functional activity both of cells and of fibres; the impulses are retarded, and thus the length of nervous connection between the cells of the spinal cord, which is calculated to keep them in proper relation in the normal animal, just suffices at a certain stage to throw the impulses half a wave-length behind the other, and thus to cause complete inbibition and apparent paralysis.

As the action of the drug goes on, the retardation becomes still greater, and then the impulses are thrown very nearly, but not quite, a whole wave-length behind the other, and thus they coincide for a short time, but gradually again interfere, and therefore we get on the application of a stimulus, a tonic convulsion followed by several clonic ones, and then by a period of rest. This explanation is further borne out by the fact observed by Fraser, that the convulsions caused by atropia occurred more readily during winter, when the temperature of the laboratory is low and the cold would tend to aid the action of the druy in retarding the transmission of impulses. ${ }^{3}$

The effect of strychnia in causing tetanus is very remarkable; a very small dose of it administered to a frog first renders the animal most sensitive to reflex impulses, so that slight impressions which would normally have no effect, produce reflex action. As the poisoning proceeds, a slight stimulus no longer produces a reflex action limited to a few muscles, but causes a general convulsion throughout all the body, all muscles being apparently put equally on the stretch. In man the form assumed by the body is that of a bow, the head and the heels being bent backwards, the hands clenched, and the arms tightly drawn to the body.

2 Marshall Hall, Menoirs on the Nerv sus System, p. vii. (London, 1837) Witkowski. Archiv für exper Path. unf Pharm., Band vii. p. 247 ${ }_{3}$ Transacti ns of the Royal Syciety of Edinburgh, vol. xxv. p. 467. 